\title{
CUSTOMER SATISFACTION AND CORPORATE INVESTMENT POLICIES
}

\author{
Lai Van VO', Huong Thi Thu LE' ${ }^{2}$, Danh Vinh $\mathrm{LE}^{3}$, \\ Minh Tuan PHUNG ${ }^{4}$, Yi-Hsien WANG ${ }^{5}$, Fu-Ju YANG ${ }^{6}$ \\ ${ }^{1}$ Department of Finance, Ancell School of Business, Western Connecticut State University, \\ 181 White Street, Danbury, CT 06810, United States \\ ${ }^{2}$ College of Business and Management, Northeastern Illinois University, \\ 5500 North St. Louis Avenue, Chicago, IL 60625, United States \\ ${ }^{3}$ Faculty of Business Administration, Ton Duc Thang University, No 19, \\ Nguyen Huu Tho street, Tan Phong ward, District 7, Ho Chi Minh City, Vietnam \\ ${ }^{4}$ Graduate Institute of International Business Administration, Chinese Culture University, \\ 55, Hwa-Kang Rd., Yang-Ming-Shan, Taipei, 11114 Taiwan \\ ${ }^{5,6}$ Department of Banking \& Finance, Chinese Culture University, 55, \\ Hwa-Kang Rd., Yang-Ming-Shan, Taipei, 11114 Taiwan \\ E-mails: ${ }^{1}$ vol@wcsu.edu; ${ }^{2} h$-le9@neiu.edu; ${ }^{3}$ levinhdanh@tdt.edu.vn; \\ 4phungminhtuan0308@gmail.com (corresponding author); \\ 5holland@mail2000.com.tw; 6fuju@faculty.pccu.edu.tw \\ Received 08 August 2016; accepted 08 January 2017
}

\begin{abstract}
This paper examines the effect of satisfaction with firms' products and services on their capital investment policies. Using data from the American Customer Satisfaction Index from 1994 to 2013, the results of the regression models show that firms with higher customer satisfaction will invest more heavily in capital expenditures in the future. The results further show that this positive effect is more pronounced for firms with less growth opportunities or a high cost of capital. This would include those firms with low market-to-book ratios, young and small firms, or firms in more competitive industries. Overall, this study argues that customer satisfaction is an important factor affecting the firm's investment policy. The findings provide a better understanding of the role of customer satisfaction which can generate growth opportunities, reduce cost and motivate a firm to invest more in capital.
\end{abstract}

Keywords: capital investments, cash flow fluctuation, customer satisfaction, cost of capital, growth opportunities, marketing-finance interface.

JEL Classification: G31, G32, M31.

\section{Introduction}

Customer satisfaction with firms' products and services has attracted attention from both public media and academics (Ludvigson 2004). However, the literature on this topic mainly examines its effects on a firm's customer retention and loyalty (e.g., Bolton 
1998; Ennew et al. 2015; Sengupta et al. 2015), on firm's performance and value (Gruca, Rego 2005; Saeidi et al. 2015), or on a firm's stock prices and returns (Aksoy et al. 2008; Jacobson, Mizik 2009; Rego et al. 2013; Sorescu, A., Sorescu, S. 2016), or on a firm's stock market risk (Fornell et al. 2006; Tuli, Bharadwaj 2009). Little is known about firm decision making when they have high customer satisfaction. In this paper, we investigate whether customer satisfaction would have effect on a firm's capital investments, which is one of a firm's core business activities as well as a component of its economic growth.

How does customer satisfaction lead to higher future capital investments? First, since customer satisfaction reflects both recent customer experiences and expectations of the quality of a firm's products and services, a high level of customer happiness should generate high customer base, resulting in high expected cash flows as well as expansion opportunities for the firm in the future. Noordewier et al. (1990) show that customers tend to purchase more from firms with which they have a greater commitment, especially during bad economic times. Fornell et al. (2010) show that customer satisfaction lead to high customer spending and high future demand. As a result, Gruca and Rego (2005) document that firms with high customer satisfaction have more future cash flow. Aksoy et al. (2008) show that firms with improvement in customer satisfaction have higher future valuations. One the other hand, Anderson et al. (1994) argue that these firms will also evidence higher profitability. Second, because high customer satisfaction generates a loyal and stable customer base (e.g., Bolton 1998; Mittal, Kamakura 2001; Sengupta et al. 2015), it can reduce a firm's cash flow fluctuations (Tuli, Bharadwaj 2009) as well as the cost of capital for such firms in the future. Consistent with this argument, Tuli and Bharadwaj (2009) find that investments in customer satisfaction help firms reduce both systematic and idiosyncratic risks. Therefore, according to the neoclassical investment theory, high customer satisfaction provides incentives for firms to expand their business operations by investing more in capital.

To further explore these mechanisms, we examine the effects of customer satisfaction on a firm's capital expenditures for different types of firms. Tobin's Q theory of investments argues that firms with high growth opportunities will invest more because their market value will be higher than the value of the replacement costs of their assets (Dixit, Pindyck 1994). Therefore, if customer satisfaction generates more expected cash flows for firms in the future, its effect on capital expenditures is expected to be stronger for firms with less growth opportunities. Consistent with this expectation, using the market-to-book ratio to capture a firm's growth opportunities, we show that firms with low market-to-book ratios will invest more in capital expenditures when they have high customer satisfaction.

If high customer happiness can reduce the cost of capital due to both low systematic risk and low idiosyncratic risk, we expect that its effect on a firm's capital investments is more pronounced for firms with high cost of capital or high financial risks. Finance literature widely uses firm age and size to capture the firm's capacity to raise capital. This is because young or small firms tend to have less collateral, poor reputations, and small market power (Borisova, Brown 2013; Vo, Le 2016). Moreover, these firms are 
riskier because their cash flows are more volatile. Using data from COMPUSTAT, we demonstrate that the effect of customer satisfaction on a firm's capital investments is indeed stronger for young and small firms.

In addition to a firm's inherent characteristics, industry competition also affects both a firm's growth opportunities and cost of capital. First, since high product market competition deteriorates firms' growth opportunities (Zhang 2005), firms in more competitive industries tend to have fewer growth options and their value highly depends on their assets-in-place (Zhang 2005; Aguerrevere 2009). This means that these firms tend to be riskier especially during bad economic times when the value of asset liquidation is largely discounted. Second, product market competition makes firms' cash flows more volatile and increases firms' default probability (Valta 2012), causing a high cost of capital. Therefore, we expect that the effect of customer satisfaction on a firm's capital investments is stronger for firms in more competitive industries.

\section{Research background}

According to neoclassical investment theory, a firm's investment decisions are mainly affected by two major determinants: the expected return on investment and the cost of capital. This approach is called Tobin's (1969) well-known Q theory, comparing the firm's $Q$ ratio (the marginal valuation of a unit capital), with the marginal cost of investment. Since the Tobin's Q reflects both the expected cash flows and the cost of capital, firms should invest more when they have high growth opportunities or low costs.

Because the market is not frictionless as is otherwise assumed by neoclassical investment theory, a firm's investment decision is more complicated. Recent literature on a firm's investment policy documents that both asymmetric information and agency problems are highly influential (Myers, Majluf 1984; Jensen 1986). Myers and Majluf (1984) show that raising external capital will be generally problematic since it dilutes the value of current shares. As a result, a firm's investment policy is highly dependent on the firm's cash flows. On the other hand, Jensen (1986) shows that firms will invest more when they are more profitable (high internal funds). Nevertheless, both theories document that the level of investment is sensitive to a firm's cash flows.

Since the analysis of corporate investments has been the focus of the finance literature for the last several decades, the empirical literature on this topic is large ${ }^{1}$. However, these studies are mostly concerned with the effects of cash flow on investments (Fazzari et al. 1988; Hubbard et al. 1995), the effects of herding on investments (Grinblatt et al. 1995), CEO confidence and corporate investments (Malmendier, Tate 2005), management forecast quality and investment (Goodman et al. 2014), and uncertainty and investments (Pindyck 1991; Bulan 2005; Panousi, Papanikolaou 2012). Our paper differs from these works in that we employ a main marketing variable, the customer satisfaction index, and examine its impact on the firm's investment decisions.

\footnotetext{
${ }^{1}$ More detailed information can be found in Stein (2001)
} 
Since customer satisfaction is a core concept in marketing, it has attracted attention from several researchers. Fornell et al. (1996) document that the American Customer Satisfaction Index has a positive relationship with customer repurchase intention and loyalty. Similarly, Bolton (1998) shows the negative impact of customer satisfaction on customer complaints. Mithas et al. (2004) demonstrate that firms with high customer satisfaction tend to have less likelihood of customer defection. Therefore, high customer satisfaction can induce high usage levels (Bolton et al. 2000) thus generating high future revenue (Rust et al. 2002). Anderson et al. (1994) also show that customer satisfaction may reduce costs related to warranties, complaints, and defective goods thus increasing a firm's profitability. Recently, several studies document that customer satisfaction is an important determinant of a firm's value and stock returns. Using Iranian manufacturing and consumer product firms, Saeidi et al. 2015 also document the positive relation between customer satisfaction and firm performance. Aksoy et al. (2008) find that a stock portfolio consisting of firms with high levels and positive changes in customer satisfaction will outperform three possible portfolio combinations (low levels and negative changes, low levels and positive changes, and high levels and negative changes in customer satisfaction) along with Standard \& Poor's 500. Jacobson and Mizik (2009) further show that this outperformance mainly comes from firms in high tech industries. In addition to high stock value, firms with high customer satisfaction tend to have low stock market risk. Fornell et al. (2006) and Sorescu, A. and Sorescu, S. (2016) find that investments in stocks of firms with high customer satisfaction earn high returns but have low risk. Merrin et al. (2013) demonstrate that customer satisfaction is a tool to evaluate sentimental stock-price movement. They show that the higher (lower) the levels of customer satisfaction the smaller (greater) a price correction and higher returns after periods of high investor sentiment. Tuli and Bharadwaj (2009) find that "investments in customer satisfaction insulate a firm's stock returns from market movements (overall and downside systematic risk) and lower the volatility of its stock returns (overall and downside idiosyncratic risk)". This result is widely discussed in the marketing literature (Gruca, Rego 2005; Fornell et al. 2006).

Recent literature also examines the determinants of customer satisfaction or the impact of customer satisfaction on business strategies. Söderlund and Colliander (2015) find that equity-reward and over-reward produced higher customer satisfaction. Luo et al. (2014) find that firms with high customer satisfaction tend to attract more transient institutional investors than non-transient institutional investors. Swaminathan et al. (2014) shows that merging firms should focus on improving customer satisfaction and improving efficiency to maximize long-term firm value.

\section{Sample selection, variable measurement, and descriptive statistics}

\subsection{Sample selection and variable measurement}

Our paper uses two data sources. First, we collect annual financial data from COMPUSTAT from 1994 to 2013 and use this data to calculate sales volume, total assets, book value of equity, market capitalization, capital expenditures, long term debt, tangible 
assets, earning on equity, firm age and Z-scores. Following Pastor and Veronesi (2006), we define book value of equity as stockholders' book value of equity plus deferred taxes minus book value of preferred stocks. We then define the market-to-book ratio (M/B) as the fraction of a firm's equity capitalization to its book value of equity. Firm size is the logarithm of firm's total assets. Return on equity (ROE) is the ratio of profits to book value of equity at the end of fiscal year, where profits are the sum of income before extraordinary items available for common stocks, deferred taxes from the income statement, investment tax credit and total interest expense (financial services). Total debt ratio is the portion of total debt to total assets and $R \& D$ ratio is the ratio of $R \& D$ expenditures to total sales. We also use COMPUSTAT annual data to calculate the firm's age which is assigned the value of one in the year when this firm appears in the dataset and increases by one in each subsequent year. To avoid the effects from outliers, we winsorize all financial variables used in our paper at the 1st and 99th percentile before merging this data and ACSI data sets. These variables are discussed in Appendix 1. We also use the sales data from COMPUSTAT to calculate the Herfindahl index which is used to measure industry concentration. In detail, this index is defined as follows:

$$
H H I(\text { Sale })_{j}=\sum_{i=1}^{I} s_{i j}^{2},
$$

where: $s_{i j}$ - the proportion of sales of firm $i$ in industry $j ; i$ - the number of firms in industry; $j$ - industry using 3-digit SIC codes.

The second dataset used in this paper is the customer satisfaction data from the American Customer Satisfaction Index (ACSI). Because the customer satisfaction index is available for each product or service of the surveyed firms, we use two methods to compute the overall customer satisfaction score for each firm. First, we define the overall customer satisfaction score for each firm as the maximum score for any product or service of that firm. Second, we calculate the average customer satisfaction index for each firm by averaging all customer satisfaction scores for all products and services of that firm. After merging COMPUSTAT and ACSI data sets, our final sample includes 180 individual firms with 1,920 firm-year observations.

Since first published in October 1994, the ACSI has been updated quarterly. The ACSI data for a calendar year t-1 has released in that year for firms in most industries and in February in year $t$ for firms in retail industry. Because the purpose of this paper is to examine the effect of customer satisfaction on firm's future capital investments, we require the firm's customer satisfaction information to be available before the firm's fiscal year when merging the ACSI data and COMPUSTAT. Since the customer satisfaction information for firms in retail industry has been available in February next year, we use customer satisfaction in year $\mathrm{t}-1$ for these firms for the fiscal year $t$. Thus the customer satisfaction information in year $t$ is available for firms in that year.

\subsection{Descriptive statistics}

Table 1 summarizes the descriptive statistics for the key variables used in our paper. The average firm age in the sample is 31.01 years. The average firm size is 9.28 (log millions) with an average Z-score of 3.57. The results from Table 1 show that the logarithm 
of a firm's customer satisfaction score varies from 3.89 to 4.51 with the average of 4.34 . The $75^{\text {th }}$ percentile of the logarithm of a firm's maximum customer satisfaction score (CS) and of is 4.41, while this figure of a firm's average customer satisfaction score (CS) is 4.40 . However, both values at $25^{\text {th }}$ and $50^{\text {th }}$ percentiles are 4.29 and 4.34 , respectively.

Table 1. Descriptive statistics

\begin{tabular}{|c|c|c|c|c|c|c|c|c|}
\hline Variable & Max & Min & Mean & Std & 25 th & 50 th & 75 th & $\mathrm{N}$ \\
\hline$C S$ & 4.51 & 3.89 & 4.34 & 0.09 & 4.29 & 4.34 & 4.41 & 1,920 \\
\hline$C S A$ & 4.51 & 3.89 & 4.34 & 0.08 & 4.29 & 4.34 & 4.40 & 1,920 \\
\hline CESALE & 1.52 & 0.00 & 0.09 & 0.10 & 0.03 & 0.06 & 0.12 & 1,920 \\
\hline CEAT & 0.42 & 0.00 & 0.06 & 0.04 & 0.03 & 0.05 & 0.08 & 1,920 \\
\hline$M B$ & 31.55 & 0.20 & 3.74 & 4.67 & 1.22 & 2.16 & 4.20 & 1,920 \\
\hline LSALE & 10.69 & -2.24 & 9.26 & 1.35 & 8.72 & 9.41 & 10.39 & 1,920 \\
\hline$L A T$ & 10.97 & 2.65 & 9.28 & 1.38 & 8.52 & 9.45 & 10.40 & 1,920 \\
\hline TOTALDEBT & 10.90 & 0.53 & 9.43 & 1.36 & 8.79 & 9.66 & 10.46 & 1,920 \\
\hline$R O A$ & 0.73 & 0.00 & 0.30 & 0.15 & 0.19 & 0.31 & 0.40 & 1,920 \\
\hline$T A N G$ & 0.28 & -0.86 & 0.05 & 0.07 & 0.03 & 0.05 & 0.08 & 1,920 \\
\hline Zscore & 0.89 & 0.01 & 0.39 & 0.21 & 0.21 & 0.38 & 0.57 & 1,920 \\
\hline$A G E$ & 56.80 & -2.44 & 3.57 & 4.57 & 1.28 & 2.66 & 4.39 & 1,920 \\
\hline RDSALE & 4.06 & 0.69 & 3.43 & 0.70 & 3.00 & 3.78 & 3.99 & 1,920 \\
\hline
\end{tabular}

Note: Definitions of the variables can be found in Appendix 1.

The main variables used in this paper are the firm's capital investments scaled by total assets (CEAT) and scaled by sales (CESALE). Table 1 shows that the average value of CEAT is 0.06 . This means that on average firms in our sample spend 6 cents per dollar asset on capital expenditures. This table also reports that the maximum and minimum values of the proportion of capital expenditures to total assets are 0.42 and 0.00 , respectively. Similarly, the average CESALE is 0.09, implying that on average sample firms spend 9 cents per every dollar sale on capital investments. Neoclassical investment theory focuses on Tobin's Q. Since the replacement cost of assets is not directly estimated from the markets, we follow the previous literature (Cao et al. 2008) to use market-to-book ratio as a proxy for a firm's investment opportunities. The results from Table 1 show that the average firm's market-to-book is 3.74 with a maximum value of 31.55 and a minimum value of 0.20 . These figures are relatively higher than the values documented in previous studies (Pastor, Veronesi 2003) ${ }^{2}$ which is also consistent with our sample of larger firms as mentioned above ${ }^{3}$.

${ }^{2}$ For example, Pastor and Veronesi (2003) report that the average market-to-book ratio for their sample is from 1.25 to 2.25 . However, their sample includes all non-financial firms with market-to-book between 0.01 and 100 .

${ }^{3}$ Similarly, Edmans (2011) focuses on 100 best companies with employee satisfaction data and documents that the average market-to-book ratio is from 2.41 to 5.20 . 


\section{Customer satisfaction and corporate investment policies}

\subsection{Regression specifications}

To explore the effect of customer satisfaction on capital investment decisions, we start with the following regression model:

$$
\triangle \text { INVEST }_{i, t+1}=\beta_{0}+\beta_{1} \text { GROWTH }_{i, t}+\beta_{2} C S_{i, t}+f_{i}+y_{t}+\varepsilon_{i, t},
$$

where: $i$ - firm i; $t$ - year $\mathrm{t}$; $\triangle I N V E S T$ - measure of the change in firm's capital investments; GROWTH - a proxy for firm's growth opportunities; $C S$ - firm's customer satisfaction; $f_{i}$ - a firm dummy; $y_{t}$ - year dummy.

According to neoclassical investment theory, firms with high growth opportunities tend to invest more in capital. Therefore, these opportunities must be considered when examining the effect of customer satisfaction on firm's investments. In addition, the since propensity to invest might be different for different firms, the firm fixed effects should be controlled. We further control for time effects because both customer satisfaction and firm's capital investments are related to business cycles, as discussed in Tuli and Bharadwaj (2009) and Panousi and Papanikolaou (2012). Since we do not have any precise measure to capture firm's growth opportunities, we follow Cao et al. (2008) to use market-to-book ratio to proxy for firm's growth opportunities. We also control for some other variables which are potentially correlated with firm's capital investment and customer satisfaction. Following Stein (2003) and Panousi and Papanikolaou (2012), we add firm size, age and profitability into model (2). As discussed in Gruca and Rego (2005), we control for sale volume and $R \& D$ expenditure because these variables may be correlated with firm's customer satisfaction. Further, we include a firm's tangible assets and total debt ratio, and ZSCORE to the regression model to control for the effect of financing resources on firm's investments.

As discussed in the Introduction section, our main independent variable, customer satisfaction, is a measure of the customer's experience and anticipation of the quality of a firm's products and services. Different from other types of investments such as R\&D, capital investment is capital expenditure on fixed assets which is mainly related to product quantity. Therefore, it is less likely for this type of investment to have any direct effect on customer satisfaction. This means that the endogeneity problem arising from the relationship between customer satisfaction and the error terms of regression model (2) will be less likely to occur. However, we still control for lagged capital investments in this regression model.

To reduce the simultaneous effect of customer satisfaction on firm's capital investment, we allow the 1 and 2 year-lag between them. To summarize, we use the following base-line regression to examine the effect of customer satisfaction on change in firm's capital investments:

$\operatorname{IINVEST}_{i, t+k}=\beta_{0}+\beta_{1} M B_{i, t}+\beta_{2} C S_{i, t}+\beta_{3} C E_{i, t}+\beta_{4}$ IIRM_CHAR $_{i, t}+f_{i}+y_{t}+\varepsilon_{i, t}$,

where: $k(k=1,2)$ - the number of year in the future; $\triangle I N V E S T$ - a measure of the 
change in capital expenditures to total assets ( $\triangle \mathrm{CEAT})$, or total sales ( $\triangle \mathrm{CESALE)}$; $C E$ - either the ratio of capital expenditure to sales (CESALE) or the ratio of capital expenditure to total assets (CEAT); FIRM_CHAR - a set of a firm's characteristics which potentially affect the firm's capital investment policies. As discussed above, high customer satisfaction can generate more growth opportunities and reduce cost of capital for firms in the future. Thus, we expect that customer satisfaction is positively correlated with a firm's future capital investments.

\subsection{Main results}

Table 2 reports the results from the regressions of the change in firm's capital investments on the customer satisfaction about its products and services and other control variables. The results from this table show that, in general, customer satisfaction is significantly positively correlated with firm's future capital investments. The t-statistics of the coefficients of customer satisfaction (CS) in Table 2a are from 2.44 to 3.05. Specially, this value in column 1 is 0.126 with a t-statistic of 2.72 , significant at the $1 \%$ level. This result implies that firms with high customer satisfaction will invest more in capital expenditures scaled by total assets. Similarly, the coefficient of customer satisfaction in column 2 is $0.073(t=3.05)$, signifying that when the customer satisfaction (in logarithm) score is increased by 1 percent, the firm will increase its capital investments by 7.3 percentage points. These results are consistent with our hypothesis that high customer satisfaction motivates firms to invest more in capital.

To check the effect of customer satisfaction on firm's future capital investments, we allow a 2-year lag between these variables. Consistent with the results in Table 2a, Table $2 \mathrm{~b}$ shows that customer satisfaction is significantly correlated with the change in firm's future investments. More interestingly, the effects of customer satisfaction on future capital investments tend to be stronger. The coefficient of customer satisfaction on the ratio of capital expenditures on sales next two years in model 1 of Table $2 b$ is 0.217 , which nearly doubles this coefficient on sales next year. This situation is similar for the coefficient of customer satisfaction on the ratio of capital investments on total assets. These results imply that customer satisfaction is an important determinant of capital investments in the future and that firms need time to absorb the information from their customers.

Previous studies (e.g. Leahy, Whited 1996; Bulan 2005) show that the market-to-book ratio is significantly positively related to a firm's capital investments. These results are consistent with the results reported in columns 1 and 2 of Table 2. However, when other firm's variables are controlled, the market-to-book ratio is insignificantly correlated with a firm's investments (columns 3 and 4 of Table 2). By contrast, customer satisfaction is still significantly correlated with the change in firm's future capital investments. This means that, as discussed in the introduction section, customer satisfaction can be used to capture a firm's growth opportunities because customer satisfaction generates a loyal and stable customer base (Tuli, Bharadwaj 2009). 
Table 2a. One-year period, customer satisfaction and capital expenditures

\begin{tabular}{|c|c|c|c|c|}
\hline & $\begin{array}{c}\triangle C E S A L E_{t+1} \\
(1)\end{array}$ & $\begin{array}{l}\Delta C E A T_{t+1} \\
\quad(2)\end{array}$ & $\begin{array}{c}\triangle C E S A L E_{t+1} \\
\text { (3) }\end{array}$ & $\begin{array}{l}\triangle C E A T_{t+1} \\
\quad(4)\end{array}$ \\
\hline$C S_{t}$ & $\begin{array}{c}0.126^{* * * *} \\
(2.72)\end{array}$ & $\begin{array}{c}0.073 * * * \\
(3.05)\end{array}$ & $\begin{array}{c}0.113^{* *} \\
(2.44)\end{array}$ & $\begin{array}{c}0.062 * * * \\
(2.97)\end{array}$ \\
\hline$C E S A L E_{t}$ & $\begin{array}{c}-0.218^{*} \\
(-1.87)\end{array}$ & & $\begin{array}{l}-0.256 \\
(-1.56)\end{array}$ & \\
\hline$C E A T_{t}$ & & $\begin{array}{c}-0.289 * * * \\
(-3.96)\end{array}$ & & $\begin{array}{c}-0.343 * * * \\
(-4.21)\end{array}$ \\
\hline$M B_{t}$ & $\begin{array}{l}0.001 * \\
(1.74)\end{array}$ & $\begin{array}{c}0.001 * * \\
(2.22)\end{array}$ & $\begin{array}{l}0.001 \\
(1.09)\end{array}$ & $\begin{array}{l}0.000 \\
(0.94)\end{array}$ \\
\hline$L S A L E_{t}$ & & & $\begin{array}{c}-0.033 * * * \\
(-4.56)\end{array}$ & $\begin{array}{l}0.002 \\
(0.29)\end{array}$ \\
\hline$L A T_{t}$ & & & $\begin{array}{c}0.023 * * * \\
(2.76)\end{array}$ & $\begin{array}{c}-0.010^{*} \\
(-1.92)\end{array}$ \\
\hline TOTALDEBT $_{t}$ & & & $\begin{array}{l}-0.014 \\
(-0.86)\end{array}$ & $\begin{array}{c}-0.023^{*} \\
(-1.82)\end{array}$ \\
\hline$R O A_{t}$ & & & $\begin{array}{l}0.015 \\
(0.24)\end{array}$ & $\begin{array}{c}0.058^{* * *} \\
(2.80)\end{array}$ \\
\hline$T A N G_{t}$ & & & $\begin{array}{l}-0.019 \\
(-0.54)\end{array}$ & $\begin{array}{l}-0.023 \\
(-1.58)\end{array}$ \\
\hline$Z_{S C O R E}$ & & & $\begin{array}{l}0.001 \\
(1.63)\end{array}$ & $\begin{array}{l}0.001 \\
(1.45)\end{array}$ \\
\hline$A G E_{t}$ & & & $\begin{array}{c}-0.056^{* *} \\
(-2.48)\end{array}$ & $\begin{array}{c}-0.033 * * * \\
(-3.29)\end{array}$ \\
\hline$R D S A L E_{t}$ & & & $\begin{array}{l}-0.146^{*} \\
(-1.84)\end{array}$ & $\begin{array}{c}-0.050^{* * * *} \\
(-2.73)\end{array}$ \\
\hline Intercept & $\begin{array}{c}-0.521^{* *} \\
(-2.56)\end{array}$ & $\begin{array}{c}-0.286^{* * *} \\
(-2.82)\end{array}$ & $\begin{array}{l}-0.196 \\
(-0.81)\end{array}$ & $\begin{array}{l}-0.047 \\
(-0.43)\end{array}$ \\
\hline Firm FE & Yes & Yes & Yes & Yes \\
\hline Time FE & Yes & Yes & Yes & Yes \\
\hline$N$ & 1,760 & 1,760 & 1,760 & 1,760 \\
\hline$R^{2}$ & 0.0825 & 0.1316 & 0.1275 & 0.2037 \\
\hline
\end{tabular}

Note: $* * *$ and $* * *$ denote statistical significance at $10 \%, 5 \%$ and $1 \%$, respectively.

In addition to the market-to-book ratio, several other variables affect a firm's investments such as firm size, age, debt, and profitability. Previous literature (e.g., Hubbard 1998; Panousi, Papanikolaou 2012) shows that old firms or firms with high debt ratios tend to have fewer growth opportunities, resulting in a tendency to invest less in capital. Consistent with these findings, our results show that firm age is negatively correlated with a firm's capital investments. Similarly, firms with high debt ratios or high tangible assets invest less in capital. 
Table 2b. Two-year period, customer satisfaction and capital expenditures

\begin{tabular}{|c|c|c|c|c|}
\hline & $\begin{array}{c}\triangle C E S A L E_{t+2} \\
\text { (1) }\end{array}$ & $\begin{array}{c}\triangle C E A T_{t+2} \\
\text { (2) }\end{array}$ & $\begin{array}{c}\triangle C E S A L E_{t+2} \\
\text { (3) }\end{array}$ & $\begin{array}{c}\triangle C E A T_{t+2} \\
\text { (4) }\end{array}$ \\
\hline$C S_{t}$ & $\begin{array}{c}0.217^{* *} \\
(2.49)\end{array}$ & $\begin{array}{c}0.109 * * * \\
(3.09)\end{array}$ & $\begin{array}{c}0.198^{* *} \\
(2.09)\end{array}$ & $\begin{array}{c}0.093 * * \\
(2.57)\end{array}$ \\
\hline$C E S A L E_{t}$ & $\begin{array}{l}-0.280 \\
(-1.09)\end{array}$ & & $\begin{array}{l}-0.336 \\
(-0.98)\end{array}$ & \\
\hline$C E A T_{t}$ & & $\begin{array}{c}-0.442 * * * \\
(-4.08)\end{array}$ & & $\begin{array}{c}-0.528 * * * \\
(-4.92)\end{array}$ \\
\hline$M B_{t}$ & $\begin{array}{c}0.002^{* *} \\
(2.10)\end{array}$ & $\begin{array}{c}0.001^{* *} \\
(2.13)\end{array}$ & $\begin{array}{l}0.002 \\
(1.38)\end{array}$ & $\begin{array}{l}0.001 \\
(1.08)\end{array}$ \\
\hline$L S A L E_{t}$ & & & $\begin{array}{c}-0.073 * * * \\
(-3.96)\end{array}$ & $\begin{array}{l}-0.005 \\
(-0.55)\end{array}$ \\
\hline$L A T_{t}$ & & & $\begin{array}{c}0.047 * * \\
(2.06)\end{array}$ & $\begin{array}{l}-0.017 \\
(-1.48)\end{array}$ \\
\hline TOTALDEBT $_{t}$ & & & $\begin{array}{l}-0.011 \\
(-0.39)\end{array}$ & $\begin{array}{l}-0.022 \\
(-0.91)\end{array}$ \\
\hline$R O A_{t}$ & & & $\begin{array}{l}-0.104 \\
(-0.65)\end{array}$ & $\begin{array}{l}0.039 \\
(1.07)\end{array}$ \\
\hline$T A N G_{t}$ & & & $\begin{array}{l}-0.016 \\
(-0.21)\end{array}$ & $\begin{array}{l}-0.035 \\
(-1.34)\end{array}$ \\
\hline$Z_{S C O R E_{t}}$ & & & $\begin{array}{c}0.002 * * * \\
(2.65)\end{array}$ & $\begin{array}{c}0.001 * * \\
(2.41)\end{array}$ \\
\hline$A G E_{t}$ & & & $\begin{array}{c}-0.093 * * \\
(-2.41)\end{array}$ & $\begin{array}{c}-0.060 * * * \\
(-3.36)\end{array}$ \\
\hline$R D S A L E_{t}$ & & & $\begin{array}{l}-0.281 \\
(-1.54)\end{array}$ & $\begin{array}{c}-0.084 * * * \\
(-2.72)\end{array}$ \\
\hline Intercept & $\begin{array}{l}-0.107 \\
(-0.27)\end{array}$ & $\begin{array}{c}-0.420 * * * \\
(-2.75)\end{array}$ & $\begin{array}{l}0.503 \\
(0.99)\end{array}$ & $\begin{array}{l}0.052 \\
(0.29)\end{array}$ \\
\hline Firm FE & Yes & Yes & Yes & Yes \\
\hline Time FE & Yes & Yes & Yes & Yes \\
\hline$N$ & 1,624 & 1,624 & 1,624 & 1,624 \\
\hline$R^{2}$ & 0.0651 & 0.1630 & 0.1133 & 0.2598 \\
\hline
\end{tabular}

Note: $* * *$ and $* * *$ denote statistical significance at $10 \%, 5 \%$ and $1 \%$, respectively.

In contrast, Table $2 \mathrm{~b}$ shows that ZSCORE is an important variable in explaining the firm's investment policies. Table $2 b$ shows that the t-statistics of ZSCORE range from 2.41 to 2.65 , statistically significant at conventional levels. Since a firm's Z-score generally captures its financial strength, this result implies that firms with high financial capacity tend to invest more in capital, consistent with the findings in the literature (e.g. Hubbard 1998; Stein 2003). 


\subsection{Addressing endogeneity problem}

To further examine the endogeneity problem raising in the relation between customer satisfaction and firm's capital investments, we employ a 2SLS regression method with instrumental variable. We use the ratio of average industry customer satisfaction to the average customer satisfaction for all firms in the markets as an external instrumental variable. This variable is calculated as follows:

$$
\operatorname{CSIND}_{j}=\frac{\frac{1}{n_{j}} \sum_{i=1}^{n_{j}} C S_{j, i}}{\frac{1}{\sum_{j=1}^{j} n_{j}} \sum_{i=1, j=1}^{n_{j}, j} C S_{j, i}},
$$

where: $C \operatorname{SIND} D_{j}$ - the ratio of average customer satisfaction for industry $j$ to the average customer satisfaction for all firms in the markets; $C S_{j, i}$ - the customer satisfaction for firm $i$ in industry $j$; $n_{j}$ - the number of firms in industry $j$. If there is only firm in a certain industry, $\operatorname{CSIND}_{j}$ is set to be equal to 1 (the ratio of market average customer satisfaction to the average customer satisfaction for all firms in the market $)^{4}$.

Before employing the regression model with instrumental variable, we test whether the ratio of industry average customer satisfaction to the whole market average customer satisfaction is a valid instrumental variable. The results (not reported) from the $1^{\text {st }}$ stage regression of firm's customer satisfaction on the ratio of industry average customer satisfaction to the whole market and other control variables shown in model (3) show that that this external instrument is significantly correlated with the firm's customer satisfaction $(t=7.41)$. We then use Cragg-Donald Wald F-statistic and Stock and Yogo test to test for weak instruments. The results show that the null hypothesis of weak instruments is rejected (F-statistic $=596.71)$, implying that the ratio of industry average customer satisfaction to the average customer satisfaction for the whole market is a valid instrument for firm's customer satisfaction.

The results in Table 3 show that firm's customer satisfaction is significantly correlated with firm's future capital investments. The t-statistics are from 1.77 to 3.38 , significant at conventional levels. Consistent with the previous results, Table 3 demonstrates that firms with high customer satisfaction will invest more in capital in the future. Moreover, in term of magnitude, after controlling for endogeneity the coefficients on customer satisfaction are much higher, suggesting that we have underestimated its effect in our base analysis shown in Table 2 .

\subsection{Customer satisfaction, firm characteristics and capital investments}

Following the recent literature (Cao et al. 2008; Borisova, Brown 2013; Vo, Le 2016), we use the market-to-book ratio to proxy for a firm's growth opportunities and firm age and size to capture a firm's financial condition. Specifically, firms with high M/B ratios

\footnotetext{
${ }^{4}$ Our results are fundamentally the same when we use adverting spending to total assets as an external instrumental variable.
} 
Table 3. Addressing endogeneity problem

\begin{tabular}{|c|c|c|c|c|}
\hline & $\triangle C E S A L E_{t+1}$ & $\triangle C E S A L E_{t+1}$ & $\Delta C E A T_{t+1}$ & $\Delta C E A T_{t+1}$ \\
\hline$C S_{t}$ & $\begin{array}{c}0.328 * * * \\
(2.95)\end{array}$ & $\begin{array}{l}0.194^{*} \\
(1.77)\end{array}$ & $\begin{array}{c}0.192 * * * \\
(3.38)\end{array}$ & $\begin{array}{c}0.141^{* *} \\
(2.54)\end{array}$ \\
\hline CESALE ${ }_{t}$ & $\begin{array}{c}-0.225^{* * *} \\
(-7.95)\end{array}$ & $\begin{array}{c}-0.259 * * * \\
(-7.94)\end{array}$ & & \\
\hline$C E A T_{t}$ & & & $\begin{array}{c}-0.300 * * * \\
(-11.37)\end{array}$ & $\begin{array}{c}-0.347 * * * \\
(-12.83)\end{array}$ \\
\hline$M B_{t}$ & $\begin{array}{l}0.000 \\
(1.00)\end{array}$ & $\begin{array}{l}0.001 \\
(1.04)\end{array}$ & $\begin{array}{c}0.001^{* *} \\
(2.33)\end{array}$ & $\begin{array}{l}0.000 \\
(0.98)\end{array}$ \\
\hline$L S A L E_{t}$ & & $\begin{array}{c}-0.032 * * * \\
(-4.33)\end{array}$ & & $\begin{array}{l}0.002 \\
(0.62)\end{array}$ \\
\hline$L A T_{t}$ & & $\begin{array}{c}0.023 * * * \\
(3.27)\end{array}$ & & $\begin{array}{c}-0.010^{* * *} \\
(-2.78)\end{array}$ \\
\hline TOTALDEBT $_{t}$ & & $\begin{array}{l}-0.015 \\
(-0.76)\end{array}$ & & $\begin{array}{c}-0.025^{* *} \\
(-2.43)\end{array}$ \\
\hline$R O A_{t}$ & & $\begin{array}{l}0.010 \\
(0.38)\end{array}$ & & $\begin{array}{c}0.053 * * * \\
(3.85)\end{array}$ \\
\hline$T A N G_{t}$ & & $\begin{array}{l}-0.021 \\
(-0.96)\end{array}$ & & $\begin{array}{c}-0.025^{* *} \\
(-2.26)\end{array}$ \\
\hline$Z_{S C O R E}$ & & $\begin{array}{c}0.001^{* *} \\
(2.06)\end{array}$ & & $\begin{array}{c}0.001^{* *} \\
(2.41)\end{array}$ \\
\hline$A G E_{t}$ & & $\begin{array}{c}-0.056^{* * *} \\
(-5.31)\end{array}$ & & $\begin{array}{c}-0.033 * * * \\
(-6.28)\end{array}$ \\
\hline$R D S A L E_{t}$ & & $\begin{array}{c}-0.142 * * * \\
(-3.27)\end{array}$ & & $\begin{array}{c}-0.047 * * \\
(-2.25)\end{array}$ \\
\hline Intercept & $\begin{array}{c}-1.399 * * * \\
(-2.89)\end{array}$ & $\begin{array}{l}-0.554 \\
(-1.14)\end{array}$ & $\begin{array}{c}-0.806^{* * *} \\
(-3.26)\end{array}$ & $\begin{array}{l}-0.394 \\
(-1.60)\end{array}$ \\
\hline Firm FE & Yes & Yes & Yes & Yes \\
\hline Time FE & Yes & Yes & Yes & Yes \\
\hline$N$ & 1,760 & 1,760 & 1,760 & 1,760 \\
\hline$R^{2}$ & 0.0631 & 0.1244 & 0.1076 & 0.1934 \\
\hline
\end{tabular}

Note: $* * *$ and $* * *$ denote statistical significance at $10 \%, 5 \%$ and $1 \%$, respectively.

are considered as having higher growth opportunities, and small or young firms as having more financial constraints. Using model (1), we add the interaction term of the customer satisfaction score and these proxies. The regression model is shown as follows:

$$
\begin{aligned}
& \Delta I N V E S T_{i, t+1}=\beta_{0}+\beta_{1} M B_{i, t}+\beta_{2} C S_{i, t}+\beta_{3} C S_{i, t} * P R O X Y_{i, t}+ \\
& \beta_{4} C E_{i, t}+\beta_{5} F I R M_{-} C H A R_{i, t}+f_{i}+y_{t}+\varepsilon_{i, t},
\end{aligned}
$$

where: $\triangle I N V E S T$ - a measure of the change in capital expenditures to total assets $(\triangle C E A T)$, or total sales $(\triangle C E S A L E) ; C E$ - either the ratio of capital expenditure to sales 
(CESALE) or the ratio of capital expenditure to total assets (CEAT); PROXY - a measure of a firm's growth opportunities or financial constraints which is market-to-book, firm age and size; FIRM_CHAR - a set of a firm's characteristics which potentially affect the firm's capital investment policies.

Table 4 presents the results from regression model 5. The first two columns of Table 4 show the effect of the market-to-book ratio on the relationship between customer satisfaction and a firm's capital investment. The t-statistics of the interaction of $\mathrm{M} / \mathrm{B}$ and customer satisfaction in the second column is -2.57 , statistically significant at conventional level. This means that firms with less growth opportunities tend to invest more in capital when they have high customer satisfaction for their products and services.

Table 4. Customer satisfaction, firm characteristics and capital expenditures

\begin{tabular}{|c|c|c|c|c|c|c|}
\hline & \multicolumn{2}{|c|}{ Panel A: Market-to-book } & \multicolumn{2}{|c|}{ Panel B: Age } & \multicolumn{2}{|c|}{ Panel C: Size } \\
\hline & $\triangle C E S A L E_{t+1}$ & $\Delta C E A T_{t+1}$ & $\triangle C E S A L E_{t+1}$ & $\triangle C E A T_{t+1}$ & $\triangle C E S A L E_{t+1}$ & $\triangle C E A T_{t+1}$ \\
\hline$M B * C S_{t}$ & $\begin{array}{l}-0.009 \\
(-1.63)\end{array}$ & $\begin{array}{c}-0.008^{* *} \\
(-2.57)\end{array}$ & & & & \\
\hline$A G E^{*} C S_{t}$ & & & $\begin{array}{c}-0.111 * * \\
(-2.40)\end{array}$ & $\begin{array}{c}-0.063 * * \\
(-2.12)\end{array}$ & & \\
\hline$L A T^{*} C S_{t}$ & & & & & $\begin{array}{c}-0.117^{*} \\
(-1.95)\end{array}$ & $\begin{array}{c}-0.048^{*} \\
(-1.97)\end{array}$ \\
\hline$C S_{t}$ & $\begin{array}{c}0.138^{* *} \\
(2.37)\end{array}$ & $\begin{array}{c}0.081 * * * \\
(3.28)\end{array}$ & $\begin{array}{c}0.504 * * * \\
(2.70)\end{array}$ & $\begin{array}{c}0.283 * * \\
(2.51)\end{array}$ & $\begin{array}{c}1.236^{* *} \\
(2.03)\end{array}$ & $\begin{array}{c}0.519^{* *} \\
(2.14)\end{array}$ \\
\hline$C E S A L E_{t}$ & $\begin{array}{l}-0.253 \\
(-1.54)\end{array}$ & $\begin{array}{c}-0.149^{* * *} \\
(-2.81)\end{array}$ & $\begin{array}{l}-0.252 \\
(-1.56)\end{array}$ & $\begin{array}{c}-0.148^{* * *} \\
(-2.82)\end{array}$ & $\begin{array}{l}-0.265 \\
(-1.65)\end{array}$ & $\begin{array}{c}-0.155^{* * *} \\
(-2.92)\end{array}$ \\
\hline$M B_{t}$ & $\begin{array}{l}0.042 \\
(1.63) \\
\end{array}$ & $\begin{array}{c}0.034^{* *} \\
(2.59) \\
\end{array}$ & $\begin{array}{l}0.001 \\
(0.96) \\
\end{array}$ & $\begin{array}{l}0.000 \\
(1.45) \\
\end{array}$ & $\begin{array}{l}0.000 \\
(0.94) \\
\end{array}$ & $\begin{array}{l}0.000 \\
(1.44) \\
\end{array}$ \\
\hline$L S A L E_{t}$ & $\begin{array}{c}-0.032 * * * \\
(-4.59)\end{array}$ & $\begin{array}{c}-0.012 * * * \\
(-2.77)\end{array}$ & $\begin{array}{c}-0.032 * * * \\
(-4.62)\end{array}$ & $\begin{array}{c}-0.011 * * * \\
(-2.77)\end{array}$ & $\begin{array}{c}-0.036^{* * *} \\
(-4.21)\end{array}$ & $\begin{array}{c}-0.013 * * * \\
(-2.90)\end{array}$ \\
\hline$L A T_{t}$ & $\begin{array}{c}0.023 * * * \\
(2.78)\end{array}$ & $\begin{array}{l}0.006 \\
(1.42)\end{array}$ & $\begin{array}{c}0.022 * * * \\
(2.73)\end{array}$ & $\begin{array}{l}0.006 \\
(1.32)\end{array}$ & $\begin{array}{c}0.534 * * \\
(2.00)\end{array}$ & $\begin{array}{c}0.215^{* *} \\
(2.02)\end{array}$ \\
\hline TOTALDEBT $T_{t}$ & $\begin{array}{l}-0.015 \\
(-0.98)\end{array}$ & $\begin{array}{c}-0.026^{* *} \\
(-2.23)\end{array}$ & $\begin{array}{l}-0.018 \\
(-1.17)\end{array}$ & $\begin{array}{c}-0.028^{* *} \\
(-2.41)\end{array}$ & $\begin{array}{l}-0.017 \\
(-1.01)\end{array}$ & $\begin{array}{c}-0.026^{* *} \\
(-2.22)\end{array}$ \\
\hline$R O A_{t}$ & $\begin{array}{l}0.014 \\
(0.22)\end{array}$ & $\begin{array}{c}0.047 * * \\
(2.06)\end{array}$ & $\begin{array}{l}0.011 \\
(0.17)\end{array}$ & $\begin{array}{c}0.046^{* *} \\
(2.00)\end{array}$ & $\begin{array}{l}0.014 \\
(0.22)\end{array}$ & $\begin{array}{c}0.048 * * \\
(2.11)\end{array}$ \\
\hline$T A N G_{t}$ & $\begin{array}{l}-0.019 \\
(-0.54)\end{array}$ & $\begin{array}{c}-0.036^{* *} \\
(-2.45)\end{array}$ & $\begin{array}{l}-0.016 \\
(-0.47)\end{array}$ & $\begin{array}{c}-0.034^{* *} \\
(-2.39)\end{array}$ & $\begin{array}{l}-0.017 \\
(-0.49)\end{array}$ & $\begin{array}{c}-0.035^{* *} \\
(-2.41)\end{array}$ \\
\hline$Z_{S C O R E}$ & $\begin{array}{l}0.001 \\
(1.62)\end{array}$ & $\begin{array}{l}0.001 \\
(1.49)\end{array}$ & $\begin{array}{l}0.001 \\
(1.48)\end{array}$ & $\begin{array}{l}0.001 \\
(1.32)\end{array}$ & $\begin{array}{l}0.001 \\
(1.05)\end{array}$ & $\begin{array}{l}0.000 \\
(1.08)\end{array}$ \\
\hline$A G E_{t}$ & $\begin{array}{c}-0.056^{* *} \\
(-2.47)\end{array}$ & $\begin{array}{c}-0.034 * * * \\
(-3.22)\end{array}$ & $\begin{array}{c}0.422 * * \\
(2.23)\end{array}$ & $\begin{array}{c}0.238^{*} \\
(1.92)\end{array}$ & $\begin{array}{c}-0.056^{* * *} \\
(-2.82)\end{array}$ & $\begin{array}{c}-0.034 * * * \\
(-3.53)\end{array}$ \\
\hline$R D S A L E_{t}$ & $\begin{array}{c}-0.150^{*} \\
(-1.86)\end{array}$ & $\begin{array}{l}0.010 \\
(0.35)\end{array}$ & $\begin{array}{c}-0.162 * * \\
(-2.04)\end{array}$ & $\begin{array}{l}0.004 \\
(0.14)\end{array}$ & $\begin{array}{c}-0.159^{*} \\
(-1.89)\end{array}$ & $\begin{array}{l}0.008 \\
(0.26)\end{array}$ \\
\hline
\end{tabular}


End of Table 4

\begin{tabular}{lcccccc}
\hline & \multicolumn{2}{c}{ Panel A: Market-to-book } & \multicolumn{2}{c}{ Panel B: Age } & \multicolumn{2}{c}{ Panel C: Size } \\
\hline & $\Delta C E S A L E_{t+1}$ & $\Delta C E A T_{t+1}$ & $\Delta C E S A L E_{t+1}$ & $\Delta C E A T_{t+1}$ & $\Delta C E S A L E_{t+1}$ & $\Delta C E A T_{t+1}$ \\
\hline Intercept & -0.307 & -0.159 & $-1.885^{* *}$ & $-1.031^{* *}$ & $-5.053^{*}$ & $\begin{array}{c}-2.052^{*} \\
\end{array}$ \\
& $(-1.05)$ & $(-1.29)$ & $(-2.40)$ & $(-2.21)$ & $(-1.89)$ & $(-1.96)$ \\
\hline Firm FE & Yes & Yes & Yes & Yes & Yes & Yes \\
\hline Time FE & Yes & Yes & Yes & Yes & Yes & Yes \\
\hline$N$ & 1,760 & 1,760 & 1,760 & 1,760 & 1,760 & 1,760 \\
\hline$R^{2}$ & 0.1295 & 0.1673 & 0.1307 & 0.1665 & 0.1414 & 0.1710 \\
\hline
\end{tabular}

Note: $*, * *$ and $* * *$ denote statistical significance at $10 \%, 5 \%$ and $1 \%$, respectively.

The results from panels B and C of Table 4 show that both interaction terms of customer satisfaction and firm age and size on firm's capital investments are negative $\mathrm{e}^{5}$. The tstatistics of these coefficients are from -2.40 to -1.95 . This means that young and small firms will invest more in capital when they have high customer satisfaction for their products and services. These results are consistent with the hypothesis that customer satisfaction will reduce the cost of capital, motivating firms to invest more because their capital investments will be more valuable.

\subsection{Customer satisfaction, industry competition and capital investments}

Recent literature shows that high product market competition deteriorates firms' growth opportunities (Aguerrevere 2009). In addition, industry competition also highly impacts firms' cost of capital because it makes the firms' cash flows more volatile and increases firms' default probability (Valta 2012). This means that firms operating in more competitive industries tend to have fewer growth opportunities and a high cost of capital. Therefore, examining the effect of industry competition on the relationship between customer satisfaction and a firm's capital investments may provide clear evidence for our hypothesis. To measure industry competition, we use the HHI calculated from COMPUSTAT sales data. The higher the HHI-index the less competitive the industry. For each year, we divide firms into two groups based on their industry competition level. We then run a regression model (3) for firms in each group. The results are reported in Table 5.

Table 5 shows that customer satisfaction is significantly positively correlated with capital investments only for firms in competitive industries. In more concentrated industries, this effect is still positive but not significant. The results (not reported) still hold when we add an interaction term of industry index and customer satisfaction into regression model (3). Thus, consistent with our prediction, the effects of customer satisfaction on a firm's investments are more pronounced for firms in more competitive industries.

\footnotetext{
${ }^{5}$ Since young and small firms may have high growth opportunities, the impact of customer satisfaction on capital investments of these firms theoretically becomes vague. Thus, to provide more clear evidence for our hypothesis, we examine the impact of customer satisfaction on corporate investments for firms in industries with different competition in the next section.
} 
Table 5. Customer satisfaction, industry competition and capital expenditures

\begin{tabular}{|c|c|c|c|c|}
\hline & \multicolumn{2}{|c|}{ Competitive Industries } & \multicolumn{2}{|c|}{ Concentrated Industries } \\
\hline & $\Delta C E S A L E_{t+1}$ & $\Delta C E A T_{t+1}$ & $\triangle C E S A L E_{t+1}$ & $\Delta C E A T_{t+1}$ \\
\hline$C S_{t}$ & $\begin{array}{c}0.114 * * \\
(2.13)\end{array}$ & $\begin{array}{c}0.066 * * * \\
(2.87)\end{array}$ & $\begin{array}{l}0.059 \\
(0.79)\end{array}$ & $\begin{array}{l}0.013 \\
(0.37)\end{array}$ \\
\hline$C E S A L E_{t}$ & $\begin{array}{l}-0.125 \\
(-0.83)\end{array}$ & $\begin{array}{c}-0.103 * * \\
(-2.02)\end{array}$ & $\begin{array}{c}-0.802 * * * \\
(-10.46)\end{array}$ & $\begin{array}{c}-0.336 * * * \\
(-12.96)\end{array}$ \\
\hline$M B_{t}$ & $\begin{array}{l}0.001 \\
(1.30)\end{array}$ & $\begin{array}{l}0.001^{*} \\
(1.76)\end{array}$ & $\begin{array}{l}-0.001 \\
(-1.04)\end{array}$ & $\begin{array}{l}0.001 \\
(1.15)\end{array}$ \\
\hline$L S A L E_{t}$ & $\begin{array}{c}-0.032 * * * \\
(-4.50)\end{array}$ & $\begin{array}{c}-0.012 * * * \\
(-2.94)\end{array}$ & $\begin{array}{c}-0.080 * * * \\
(-2.92)\end{array}$ & $\begin{array}{c}-0.035 * * * \\
(-2.93)\end{array}$ \\
\hline$L A T_{t}$ & $\begin{array}{c}0.019 * * \\
(2.14)\end{array}$ & $\begin{array}{l}0.003 \\
(0.72)\end{array}$ & $\begin{array}{c}0.066^{* * * *} \\
(2.69)\end{array}$ & $\begin{array}{c}0.022 * * \\
(2.07)\end{array}$ \\
\hline TOTALDEBT $_{t}$ & $\begin{array}{l}-0.010 \\
(-0.52)\end{array}$ & $\begin{array}{l}-0.015 \\
(-1.12)\end{array}$ & $\begin{array}{l}0.056^{*} \\
(1.96)\end{array}$ & $\begin{array}{l}-0.012 \\
(-0.47)\end{array}$ \\
\hline$R O A_{t}$ & $\begin{array}{l}0.002 \\
(0.02) \\
\end{array}$ & $\begin{array}{c}0.059^{*} \\
(1.86) \\
\end{array}$ & $\begin{array}{l}-0.016 \\
(-0.68) \\
\end{array}$ & $\begin{array}{l}-0.015 \\
(-1.34) \\
\end{array}$ \\
\hline$T A N G_{t}$ & $\begin{array}{l}-0.031 \\
(-0.63) \\
\end{array}$ & $\begin{array}{c}-0.040 * * \\
(-2.11) \\
\end{array}$ & $\begin{array}{c}0.039 * \\
(1.70) \\
\end{array}$ & $\begin{array}{l}-0.009 \\
(-0.41) \\
\end{array}$ \\
\hline$Z_{S C O R E}$ & $\begin{array}{l}0.000 \\
(1.01)\end{array}$ & $\begin{array}{l}0.000 \\
(0.92)\end{array}$ & $\begin{array}{c}0.022 * * * \\
(4.56)\end{array}$ & $\begin{array}{c}0.010 * * * \\
(4.48)\end{array}$ \\
\hline$A G E_{t}$ & $\begin{array}{c}-0.040 * * \\
(-2.25) \\
\end{array}$ & $\begin{array}{c}-0.028 * * \\
(-2.19) \\
\end{array}$ & $\begin{array}{c}-0.052 * * \\
(-2.60) \\
\end{array}$ & $\begin{array}{c}-0.028 * * \\
(-2.43)\end{array}$ \\
\hline$R D S A L E_{t}$ & $\begin{array}{c}-0.209 * * \\
(-2.55)\end{array}$ & $\begin{array}{l}-0.011 \\
(-0.32)\end{array}$ & $\begin{array}{l}-0.316 \\
(-0.52)\end{array}$ & $\begin{array}{l}-0.709 \\
(-1.61)\end{array}$ \\
\hline Intercept & $\begin{array}{l}-0.212 \\
(-0.73)\end{array}$ & $\begin{array}{l}-0.088 \\
(-0.74)\end{array}$ & $\begin{array}{l}-0.062 \\
(-0.18)\end{array}$ & $\begin{array}{l}0.102 \\
(0.58)\end{array}$ \\
\hline Firm FE & Yes & Yes & Yes & Yes \\
\hline Time FE & Yes & Yes & Yes & Yes \\
\hline$N$ & 1,404 & 1,404 & 356 & 356 \\
\hline$R^{2}$ & 0.1052 & 0.1382 & 0.6680 & 0.5618 \\
\hline
\end{tabular}

Note: $*, * *$ and $* * *$ denote statistical significance at $10 \%, 5 \%$ and $1 \%$, respectively.

\section{Robust tests}

In the previous sections, we used the logarithm of a firm's maximum customer satisfaction score to proxy for the firm's overall customer satisfaction. Since many firms have several different products, there may be several customer satisfaction indices for a certain firm in a certain year. Therefore, in this section we robustly check our results by using an average customer satisfaction score for each firm. We run a regression of a firm's capital investments on the logarithm of the firm's average customer satisfaction score and other control variables. The results are reported in Table 6. 
Table 6. Robust tests

\begin{tabular}{|c|c|c|c|c|}
\hline & $\triangle C E S A L E_{t+1}$ & $\Delta C E A T_{t+1}$ & $\triangle C E S A L E_{t+1}$ & $\Delta C E A T_{t+1}$ \\
\hline$C S A_{t}$ & $\begin{array}{c}0.135 * * * \\
(2.84)\end{array}$ & $\begin{array}{c}0.078 * * * \\
(3.09)\end{array}$ & $\begin{array}{c}0.112 * * \\
(2.47)\end{array}$ & $\begin{array}{c}0.066 * * * \\
(2.96)\end{array}$ \\
\hline$C E S A L E_{t}$ & $\begin{array}{c}-0.218^{*} \\
(-1.87)\end{array}$ & & $\begin{array}{l}-0.254 \\
(-1.55)\end{array}$ & \\
\hline$C E A T_{t}$ & & $\begin{array}{c}-0.290 * * * \\
(-3.98)\end{array}$ & & $\begin{array}{c}-0.343 * * * \\
(-4.22)\end{array}$ \\
\hline$M B_{t}$ & $\begin{array}{l}0.001 * \\
(1.75)\end{array}$ & $\begin{array}{c}0.001 * * \\
(2.23)\end{array}$ & $\begin{array}{l}0.001 \\
(1.10)\end{array}$ & $\begin{array}{l}0.000 \\
(0.95)\end{array}$ \\
\hline$L S A L E_{t}$ & & & $\begin{array}{c}-0.032 * * * \\
(-4.54)\end{array}$ & $\begin{array}{l}0.002 \\
(0.34)\end{array}$ \\
\hline$L A T_{t}$ & & & $\begin{array}{c}0.022 * * * \\
(2.75)\end{array}$ & $\begin{array}{c}-0.010^{* *} \\
(-2.00)\end{array}$ \\
\hline TOTALDEBT $_{t}$ & & & $\begin{array}{l}-0.014 \\
(-0.88)\end{array}$ & $\begin{array}{c}-0.023^{*} \\
(-1.84)\end{array}$ \\
\hline$R O A_{t}$ & & & $\begin{array}{l}0.016 \\
(0.27)\end{array}$ & $\begin{array}{c}0.059 * * * \\
(2.85)\end{array}$ \\
\hline$T A N G_{t}$ & & & $\begin{array}{l}-0.020 \\
(-0.57)\end{array}$ & $\begin{array}{l}-0.024 \\
(-1.63)\end{array}$ \\
\hline$Z_{S C O R E}$ & & & $\begin{array}{l}0.001 \\
(1.58)\end{array}$ & $\begin{array}{l}0.001 \\
(1.41)\end{array}$ \\
\hline$A G E_{t}$ & & & $\begin{array}{c}-0.055^{* *} \\
(-2.45)\end{array}$ & $\begin{array}{c}-0.033 * * * \\
(-3.28)\end{array}$ \\
\hline$R D S A L E_{t}$ & & & $\begin{array}{c}-0.146^{*} \\
(-1.84)\end{array}$ & $\begin{array}{c}-0.049 * * * \\
(-2.71)\end{array}$ \\
\hline Intercept & $\begin{array}{c}-0.560 * * * \\
(-2.68)\end{array}$ & $\begin{array}{c}-0.309 * * * \\
(-2.86)\end{array}$ & $\begin{array}{l}-0.193 \\
(-0.80)\end{array}$ & $\begin{array}{l}-0.062 \\
(-0.55)\end{array}$ \\
\hline Firm FE & Yes & Yes & Yes & Yes \\
\hline Time FE & Yes & Yes & Yes & Yes \\
\hline$N$ & 1,760 & 1,760 & 1,760 & 1,760 \\
\hline$R^{2}$ & 0.0838 & 0.1330 & 0.1273 & 0.2043 \\
\hline
\end{tabular}

Note: $*, * *$ and $* * *$ denote statistical significance at $10 \%, 5 \%$ and $1 \%$, respectively.

Consistent with the results in Table 2, Table 6 shows that customer satisfaction as measured by the average of all products or services satisfaction scores is significantly positively correlated with a firm's capital investments. The t-statistics of these coefficients are from 2.47 to 3.10, significant at the conventional levels. These results are consistent with our hypothesis that customer satisfaction can encourage firms to invest more in capital. 


\section{Conclusions}

This paper investigates the effect of customer satisfaction with a firm's products and services on its capital investments. Using panel data of publicly traded firms from COMPUSTAT and customer satisfaction data from the American Customer Satisfaction Index, we show that firms with high customer satisfaction tend to invest more in capital. Our results are robust to different definitions of customer satisfaction variables and after controlling for several of a firm's important characteristics such as marketto-book ratio, firm size, total debt ratio, profitability, tangible assets ratio, firm age and R\&D expenditure ratio. These results still hold under the 2SLS instrumental variable regression method.

We provide two underlying mechanisms for the positive effects of customer satisfaction on a firm's capital investments. First, since customer satisfaction data captures both the recent experiences and expectations of the quality of a firm's products and services, high customer satisfaction with the firms' products and services generates high expected cash flows as well as increased future growth opportunities. Second, customer satisfaction cushions a firm's cash flows from the fluctuations of the markets, and thus lowers its cost of capital.

To test the validity of these mechanisms, we examined the effects of firm and industry characteristics on the relationship between customer satisfaction and a firm's capital investments. We find that firms with fewer growth opportunities (captured by marketto-book ratios) tend to invest more when they have high customer satisfaction. This positive effect is also more pronounced for small and young firms. Similarly, we find that firms in more competitive industries tend to invest more in capital expenditures when they have high customer satisfaction.

Overall, our results demonstrate that customer satisfaction, a firm's intangible asset, is an important factor affecting a firm's investment policy. High customer satisfaction motivates firms to invest more in capital expenditures.

Our paper makes several contributions to the literature. First, we show that customer satisfaction (intangible asset) is an important factor affecting the firm's investment policy. Second, whereas the literature in marketing mainly focuses on the effects of customer satisfaction on firm value, firm performance and firm risk, our paper investigates the effect of customer satisfaction on a firm's capital investment, which is a core business activity of the firm as well as a main driver of economic growth. We show that customer satisfaction motivates firms to invest more in capital.

To the best of our knowledge, this is the first empirical paper investigating the effect of customer satisfaction on a firm's capital investments. We show that customer satisfaction contributes to a loyal and stable customer base which can generate growth opportunities and reduce cost of capital for the firm, motivating a firm to invest more in capital. We also document that this positive effect is more pronounced for small and young firms or firms in more competitive industries.

This paper provides empirical results showing the effect of customer satisfaction on corporate investment policies. We leave the theoretical contributions for future research. 


\section{Acknowledgment}

This work was supported by the Ministry of Science and Technology of Taiwan under Contract No. NSC102-2410-H034-027.

\section{References}

Aguerrevere, F. L. 2009. Real options, product market competition, and asset returns, The Journal of Finance 64(2): 957-983. https://doi.org/10.1111/j.1540-6261.2009.01454.x

Aksoy, L.; Groening, C.; Keiningham, T. L.; Yalcin, A. 2008. The long-term stock market valuation of customer satisfaction, Journal of Marketing 72(4): 105-122.

https://doi.org/10.1509/jmkg.72.4.105

Anderson, E.W.; Fornell, C.; Lehmann, D. R. 1994. Customer satisfaction, market share, and profitability: findings from Sweden, Journal of Marketing 58(3): 53-66.

https://doi.org/10.2307/1252310

Bolton, R. N. 1998. A dynamic model of the duration of the customer's relationship with a continuous service provider: the role of satisfaction, Marketing Science 17(1): 45-65.

https://doi.org/10.1287/mksc.17.1.45

Bolton, R. N.; Kannan, P. K.; Bramlett, M. D. 2000. Implications of loyalty program membership and service experiences for customer retention and value, Journal of the Academy of Marketing Science 28(1): 95-108. https://doi.org/10.1177/0092070300281009

Borisova, G.; Brown, J. R. 2013. R\&D sensitivity to asset sale proceeds: new evidence on financing constraints and intangible investment, Journal of Banking and Finance 37(1): 159-173. https://doi.org/10.1016/j.jbankfin.2012.08.024

Bulan, L. T. 2005. Real options, irreversible investment and firm uncertainty: new evidence from U.S. firms, Review of Financial Economics 14(3-4): 255-279.

https://doi.org/10.1016/j.rfe.2004.09.002

Cao, C.; Simin, T.; Zhao, J. 2008. Can growth options explain the trend in idiosyncratic risk?, The Review of Financial Studies 21(6): 2599-2633. https://doi.org/10.1093/rfs/hhl039

Dixit, A. K.; Pindyck, R. S. 1994. Investment under uncertainty. First printing ed. Princeton, NJ: Princeton University Press.

Edmans, A. 2011. Does the stock market fully value intangibles? Employee satisfaction and equity prices, Journal of Financial Economics 101 (3): 621-640.

http://dx.doi.org/10.1016/j.jfineco.2011.03.021

Ennew, C. T.; Binks, M. R.; Chiplin, B. 2015. Customer satisfaction and customer retention: an examination of small businesses and their banks in the UK, in E. J. Wilson, W. C. Black (Eds.). Proceedings of the 1994 Academy of Marketing Science (AMS) Annual Conference. Springer International Publishing, 188-192. https://doi.org/10.1007/978-3-319-13162-7_49

Fazzari, S.; Hubbard, R. G.; Petersen, B. C. 1988. Financing constraints and corporate investment, Brookings Papers on Economic Activity 1: 141-195. https://doi.org/10.2307/2534426

Fornell, C.; Mithas, S.; Morgeson III, F. V.; Krishnan, M. S. 2006. Customer satisfaction and stock prices: high returns, low risk, Journal of Marketing 70(1): 3-14.

https://doi.org/10.1509/jmkg.2006.70.1.3

Fornell, C.; Johnson, M. D.; Anderson, E. W.; Cha, J.; Bryant, B. E. 1996. The American customer satisfaction index: nature, purpose, and findings, Journal of Marketing 60(4): 7-18. https://doi.org/10.2307/1251898

Fornell, C.; Rust, R. T.; Dekimpe M. G. 2010. The effect of customer satisfaction on consumer spending growth, Journal of Marketing Research 47(1): 28-35.

https://doi.org/10.1509/jmkr.47.1.28 
Goodman, T. H.; Neamtiu, M.; Shroff, N.; White, H. D. 2014. Management forecast quality and capital investment decisions, The Accounting Review 89(1): 331-365.

https://doi.org/10.2308/accr-50575

Grinblatt, M.; Titman, S.; Wermers, R. 1995. Momentum investment strategies, portfolio performance, and herding: a study of mutual fund behavior, The American Economic Review 85(5): 1088-1105.

Gruca, T. S.; Rego, L. L. 2005. Customer satisfaction, cash flow, and shareholder value, Journal of Marketing 69(3): 115-130. https://doi.org/10.1509/jmkg.69.3.115.66364

Hubbard, R. G.; Kashyap, A. K.; Whited, T. M. 1995. Internal finance and firm investment, Journal of Money, Credit and Banking 27(3): 683-701. https://doi.org/10.2307/2077743

Hubbard. G. 1998. Capital-market imperfections and investment, Journal of Economic Literature 36(1): 193-225.

Jacobson, R.; Mizik, N. 2009. The financial markets and customer satisfaction: reexamining possible financial market mispricing of customer satisfaction, Marketing Science 28(5): 810-819. https://doi.org/10.1287/mksc.1090.0495

Jensen, M. 1986. Agency cost of free cash flow, corporate finance and takeovers, American Economic Review, Papers and Proceedings 76(2): 323-329.

Leahy, J. V.; Whited, T. M. 1996. The effect of uncertainty on investment: some stylized facts, Journal of Money, Credit and Banking 28(1): 64-83. https://doi.org/10.2307/2077967

Ludvigson, S. C. 2004. Consumer confidence and consumer spending, Journal of Economic Perspectives 18(2): 29-50. https://doi.org/10.1257/0895330041371222

Luo, X.; Zhang, R.; Zhang, W.; Aspara, J. 2014. Do institutional investors pay attention to customer satisfaction and why?, Journal of the Academy of Marketing Science 42(2): 119-136. https://doi.org/10.1007/s11747-013-0342-9

Malmendier, U.; Tate, G. 2005. CEO overconfidence and corporate investment, The Journal of Finance 60(6): 2661-2700. https://doi.org/10.1111/j.1540-6261.2005.00813.x

Merrin, R. P.; Hoffmann, A. O. I.; Pennings, J. M. E. 2013. Customer satisfaction as a buffer against sentimental stock-price corrections, Marketing Letters 24(1): 13-27.

https://doi.org/10.1007/s11002-012-9219-9

Mithas, S.; Jones, J. L.; Mitchell, W. 2004. Determinants of governance choice in business-tobusiness electronic markets: an empirical analysis. Working paper. Ross School of Business, University of Michigan.

Mittal, V.; Kamakura, W. A. 2001. Satisfaction, repurchase intent, and repurchase behavior: investigating the moderating effect of customer characteristics, Journal of Marketing Research 38(1): 131-142. https://doi.org/10.1509/jmkr.38.1.131.18832

Myers, S. C.; Majluf, N. 1984. Corporate financing and investment decisions when firms have information that investors do not have, Journal of Financial Economics 13(2): 187-221.

https://doi.org/10.1016/0304-405X(84)90023-0

Noordewier, T. G.; John, G.; Nevin, J. R. 1990. Performance outcomes of purchasing arrangements in industrial buyer-vendor relationships, Journal of Marketing 54(4): 80-93.

https://doi.org/10.2307/1251761

Panousi, V.; Papanikolaou, D. 2012. Investment, idiosyncratic risk, and ownership, The Journal of Finance 67(3): 1113-1148. https://doi.org/10.1111/j.1540-6261.2012.01743.x

Pastor, L.; Veronesi, P. 2003. Stock valuation and learning about profitability, The Journal of Finance 58(5): 1749-1789. https://doi.org/10.1111/1540-6261.00587

Pastor, L.; Veronesi, P. 2006. Was there a Nasdaq bubble in the late 1990s?, Journal of Financial Economics 81(1): 61-100. https://doi.org/10.1016/j.jfineco.2005.05.009 
Pindyck, R. S. 1991. Irreversibility, uncertainty, and investment, Journal of Economic Literature 29(3): 1110-1148.

Rego, L. L; Morgan, N. A.; Fornell, C. 2013. Reexamining the market share-customer satisfaction relationship, Journal of Marketing 77(5): 1-20. https://doi.org/10.1509/jm.09.0363

Rust, R. T.; Moorman, C.; Dickson, P. R. 2002. Getting return on quality: revenue expansion, cost reduction, or both?, Journal of Marketing 66(4): 7-24. https://doi.org/10.1509/jmkg.66.4.7.18515 Sengupta, A. S.; Balaji, M. S.; Krishnan, B.C. 2015. How customers cope with service failure? A study of brand reputation and customer satisfaction, Journal of Business Research 68(3): 665-674. https://doi.org/10.1016/j.jbusres.2014.08.005

Saeidi, S. P.; Sofian, S.; Saeidi, P.; Saeidi, S. P.; Saaeidi, S. A. 2015. How does corporate social responsibility contribute to firm financial performance? The mediating role of competitive advantage, reputation, and customer satisfaction, Journal of Business Research 68(2): 341-350.

https://doi.org/10.1016/j.jbusres.2014.06.024

Söderlund, M.; Colliander, J. 2015. Loyalty program rewards and their impact on perceived justice, customer satisfaction, and repatronize intentions, Journal of Retailing and Consumer Services 25: 47-57. https://doi.org/10.1016/j.jretconser.2015.03.005

Sorescu, A.; Sorescu, S. 2016. Customer satisfaction and long-term stock returns, Journal of Marketing 80(5): 110-115. https://doi.org/10.1509/jm.16.0214

Stein, J. C. 2003. Agency, information and corporate investment, Chapter 2 in G. M. Constantinides, M. Harris, R. M. Stulz (Eds.). Handbook of the Economics of finance. North Holland Publishing, 111-165.

Swaminathan, V.; Groening, C.; Mittal, V.; Thomaz, F. 2014. How achieving the dual goal of customer satisfaction and efficiency in mergers affects a firm's long-term financial performance, Journal of Service Research 17(2): 182-194. https://doi.org/10.1177/1094670513510196

Tobin, J. 1969. A General Equilibrium Approach to Monetary Theory, Journal of Money, Credit and Banking 1(1): 15-29. https://doi.org/10.2307/1991374

Tuli, K. R.; Bharadwaj, S. G. 2009. Customer satisfaction and stock returns risk, Journal of Marketing 73(6): 184-197. https://doi.org/10.1509/jmkg.73.6.184

Valta, P. 2012. Competition and the cost of debt, Journal of Financial Economics 105(3): 661682. https://doi.org/10.1016/j.jfineco.2012.04.004

Vo, L.V.; Le, H. 2016. Strategic growth options, uncertainty and R\&D investments, in Financial Management Association Annual Meeting, 19-22 October 2016, Las Vegas, NV, USA.

Zhang, L. 2005. The value premium, The Journal of Finance 60(1): 67-103.

https://doi.org/10.1111/j.1540-6261.2005.00725.x 


\section{APPENDIX 1}

\section{Variable definitions}

All variables are at the firm level recorded at the end of the fiscal year except where otherwise noted. COMPUSTAT variable names are in parentheses.

\begin{tabular}{|c|c|}
\hline Variable & Definition \\
\hline \multicolumn{2}{|r|}{ Main variables } \\
\hline CEAT & The ratio of capital expenditures to total assets (CE/AT) \\
\hline CESALE & The ratio of capital expenditures to sales volume (CE/SALE) \\
\hline$\triangle C E A T$ & The ratio of change in capital expenditures to total assets $(\Delta \mathrm{CE} / \mathrm{AT})$ \\
\hline$\triangle C E S A L E$ & The ratio of change in capital expenditures to sales volume ( $\triangle \mathrm{CE} / \mathrm{SALE})$ \\
\hline$C S$ & $\begin{array}{l}\text { The natural logarithm of a firm's maximum customer satisfaction score } \\
\text { (http://www.theacsi.org/) }\end{array}$ \\
\hline$C S A$ & $\begin{array}{l}\text { The natural logarithm of a firm's average customer satisfaction score } \\
\text { (http://www.theacsi.org/) }\end{array}$ \\
\hline \multicolumn{2}{|r|}{ Other variables } \\
\hline$M B$ & $\begin{array}{l}\text { The market-to-book ratio, which is the market capitalization to book equity, where } \\
\text { (PRCC_F*CSHO/BE where BE= SEQ+TXDITC -PSTKRV -PRCA) }\end{array}$ \\
\hline$L S A L E$ & The natural logarithm of total sales volume (log(SALE)) \\
\hline$L A T$ & The natural logarithm of total assets $(\log (\mathrm{AT}))$ \\
\hline TOTALDEBT & The ratio of total term debt to total assets (DTT/AT) \\
\hline$R O A$ & The ratio of earnings to total assets (IBCOM +TXDI+ITCI+TIE/AT) \\
\hline$T A N G$ & The ratio of tangible assets to total assets (PPENT/AT) \\
\hline$H H I$ & The industry competition which is calculated from COMPUSTAT \\
\hline ZSCORE & $\mathrm{Z}$-score $=1.2 * \mathrm{WCA}+1.4 * \mathrm{RE} / \mathrm{AT}+3.3 * \mathrm{EBIT} / \mathrm{at}+0.6 * \mathrm{MEF} / \mathrm{LT}+0.999 * \mathrm{SALE} / \mathrm{AT})$ \\
\hline$A G E$ & The firm age from COMPUSTAT \\
\hline RDSALE & The ratio of $R \& D$ expenditure to total sales \\
\hline
\end{tabular}

Lai Van VO, PhD, is an Assistant Professor of Finance at Western Connecticut State University, USA. His research focuses on corporate finance, financial markets, and banking. His work has been selected for presentation at leading academic conferences such as the Financial Management Association, Midwest Finance Association, and Southern Finance Association annual meetings. His research has been published in the Journal of Financial Services Research.

Huong Thi Thu LE, PhD, is an Assistant Professor of Finance at Northeastern Illinois University, USA. She currently focuses on corporate finance, firm innovation, and financial markets.

Danh Vinh LE, PhD, is the President of Ton Duc Thang University, Vietnam. He obtained his PhD Degree in International Economics at Institute of World Economics, Vietnam. He was a Fulbright International Exchange Scholar at George Washington University, USA in 2000-2001. His research interests are corporate finance, financial markets and international economics. 
Minh Tuan PHUNG is a doctoral candicate at Graduate Institute of International Business Administration, Chinese Culture University, Taiwan. His main research interests are in marketing, sport marketing.

Yi-Hsien WANG, Dr, is a Professor of the Department of Banking \& Finance, Chinese Culture University. He holds a PhD from the Graduate School of Management, Ming Chuan University. His current research focuses on investment, applied economics, and financial time series.

Fu-Ju YANG, Dr, is a Professor of the Department of Banking \& Finance, Chinese Culture University. She holds a PhD from the Institute of Business \& Management, National Chiao Tung University. Her research interests include corporate finance, financial management, and investment analysis and management. 